\title{
RANCANG BANGUN MODUL ALAT UKUR MEDICAL CHECK-UP BERBASIS MIKROKONTROLER ATMEGA8535
}

\author{
Faizatul Fitri, Wildian \\ Jurusan Fisika FMIPA Universitas Andalas, Padang \\ Kampus Unand Limau Manis, Pauh, Padang 25163 \\ e-mail: faizatulfitri1992@gmail.com
}

\begin{abstract}
ABSTRAK
Modul alat ukur medical check-up pada penelitian ini merupakan alat yang dapat mengukur temperatur tubuh, tekanan darah, dan detak jantung. Alat dirancang untuk usia dewasa dan dilengkapi dengan analisis hasil pengukuran. Pengukuran temperatur tubuh, tekanan darah, dan detak jantung secara berturut-turut menggunakan sensor temperatur LM35, sensor tekanan MPX5050DP dan pulse sensor. Alat ukur standar yang digunakan sebagai pembanding adalah termometer digital untuk pengukuran temperatur tubuh, sphygmomanometer analog untuk pengukuran tekanan darah, dan stetoskop untuk pengukuran detak jantung. Data masukan dari sensor diolah oleh mikrokontroler ATmega8535 dan ditampilkan pada layar LCD 2x16 karakter. Ketepatan pengujian modul alat ukur medical check-up untuk temperatur tubuh adalah 97,48\%, tekanan darah systole adalah 97,40\%, tekanan darah dyastole adalah 89,04\%, dan detak jantung adalah $90,36 \%$.
\end{abstract}

Kata kunci : medical check-up, ATmega8535, LCD 2x16 karakter.

\section{PENDAHULUAN}

Saat ini kesadaran masyarakat untuk melakukan pemeriksaan kesehatan masih sangat kurang. Jumlah orang yang pergi ke rumah sakit untuk tujuan melakukan pemeriksaan kesehatan masih sedikit. Salah satu faktor yang menyebabkan masyarakat kurang peduli untuk melakukan pemeriksaan kesehatan secara rutin adalah faktor ekonomi. Melakukan pemeriksaan kesehatan di rumah sakit masih dianggap sebagai sebuah tindakan pemborosan, karena selain biayanya yang relatif mahal juga fasilitas untuk itu umumnya hanya ada di kota-kota besar.

Pemantauan parameter penting pada kondisi yang sangat serius, sejumlah rumah sakit telah memiliki alat ukur dengan sistem terpadu seperti mesin anestetik. Pemeriksaan menggunakan mesin anastetik membutuhkan biaya yang relatif mahal karena mesin ini hanya terdapat di rumah sakit yang memilki fasilitas lengkap. Masyarakat semakin tidak peduli untuk memeriksakan kesehatan tubuhnya secara rutin.

Rahmawati, dkk., (2012) telah melakukan penelitian yang terkait dengan pembuatan alat ukur temperatur tubuh manusia. Dalam penelitian tersebut digunakan sensor LM35DZ yang mengonversi temperatur tubuh menjadi tegangan listrik. Hasil pengukurannya ditampilkan dalam bentuk tampilan digital dan keluaran suara.

Penelitian tentang pembuatan tensimeter digital telah dilakukan oleh Marnis (2009) dengan menggunakan sensor tekanan tipe MPX2100DP dan mikrokontroler AT89S51, dan Yazid dan Harjoko (2011) dengan sensor tekanan tipe MPX2050GP dan mikrokontroler ATmega32. Penelitian tentang pembuatan alat ukur detak jantung telah dilakukan Faisal (2008) dengan menggunakan sensor fotodioda berbasis mikrokontroler AT89S52.

Alat ukur yang dihasilkan oleh penelitian Rahmati, dkk, Marnis, Yazid dan Harjoko, dan Faisal terbatas untuk mengukur satu besaran fisis (temperatur, tekanan darah, atau detak 
jantung) saja. Oleh karena program medical check-up memerlukan pengukuran banyak besaran fisis, maka pembuatan alat ukur dalam bentuk modul yang dapat menangani beberapa pengukuran sekaligus akan sangat membantu dalam hal efisiensi waktu dan biaya.

Shaleh dkk. (2009) telah merancang-bangun pendeteksi temperatur, tekanan darah dan detak jantung untuk medical chek-up menggunakan sensor LM35, sensor tekanan MPX5100, dan mik kondensor yang diintegrasikan dengan stetoskop untuk mengukur detak jantung berbasis mikrokontroler ATmega8535. Penelitian ini memiliki kekurangan karena masih menggunakan PC (personal computer). Kekurangan lain adalah masih tingginya nilai error yang didapatkan jika dibandingkan dengan pengukuran menggunakan tensimeter digital serta hasil pengukuran tidak ditampilkan dalam bentuk keterangan normal atau tidak normal.

Penelitian ini dimaksudkan untuk melengkapi kekurangan penelitian terdahulu. Modul alat ukur yang telah dirancang meliputi pengukuran temperatur tubuh, tekanan darah, dan detak jantung. Hasil pengukuran ketiga besaran fisis tersebut akan ditampilkan pada LCD 2x16 karakter.

\section{METODE}

Penelitian ini menggunakan metode rancang-bangun alat. Metode rancang-bangun alat ini meliputi perancangan perangkat keras (hardware) dan perancangan perangkat lunak (software) dengan menggunakan bahasa pemograman BASCOM-AVR.

\subsection{Teknik Penelitian}

Teknik penelitian yang dilakukan dalam penelitian terdiri dari studi literatur, pembuatan catu daya, pengujian sistem sensor temperatur tubuh, pengujian sistem sensor tekanan darah, pengujian sistem sensor detak jantung, pengujian modul alat ukur medical checkup, pembuatan rangkaian secara permanen mulai dari penyolderan pemasangan alat dan komponen serta pengaturan sistem rangkaian, pembuatan program, pengujian akhir meliputi perangkat keras dan perangkat lunak serta analisis data.

\subsection{Karakterisasi sensor dan pengujian modul alat ukur medical check-up}

Karakterisasi sensor bertujuan untuk mengetahui apakah sensor sudah sesuai dengan karakteristik yang telah ditetapkan serta untuk mengetahui apakah sensor dapat berfungsi dengan baik. Pengujian dilakukan untuk membandingkan apakah hasil keluaran modul alat ukur medical check-up sudah sesuai dengan alat ukur standar yang digunakan sebagai pembanding. Karakterisasi sensor temperatur LM35 dilakukan dengan menghubungkan kaki 1 ke sumber tegangan $+5 \mathrm{~V}$, kaki 2 ke ground, dan kaki 3 ke output. Perubahan nilai tegangan keluaran akibat perubahan temperatur dilihat pada multimeter.

Pengujian temperatur tubuh dilakukan di permukaan kulit (jari tangan) dengan cara menjepit sensor temperatur LM35 dengan dua ujung jari dalam rentang waktu 10 detik dan alat ukur standar yang digunakan adalah termometer digital.

Sensor tekanan MPX5050DP dikarakterisasi dengan memberikan tekanan pada sensor, yaitu dengan mengalirkan udara masuk ke dalam sensor dan melihat perubahan tegangan pada multimeter digital. Kaki 1 pada sensor tekanan MPX5050DP dihubungkan ke output, kaki 2 dihubungkan ke ground, sedangkan kaki 3 dihubungkan ke sumber tegangan $+5 \mathrm{~V}$.

Pengujian sistem sensor tekanan darah dilakukan menggunakan airpump dan valve sebagai pemompa, manset (handcuff) dan tombol reset. Airpump akan memompakan udara ke dalam manset, sementara sensor tekanan MPX5050DP yang mendeteksi tekanan 
udara di dalam manset akan secara terus menerus memantau tekanan hingga mencapai tekanan $\pm 200 \mathrm{mmHg}$. Ketika tekanan $\pm 200 \mathrm{mmHg}$ sudah tercapai, aliran darah akan terhenti untuk sementara karena manset menekan kuat pembuluh darah yang menyebabkan pembuluh nadi menyempit. Selanjutnya, valve dibuka perlahan dan tekanan pada manset akan secara perlahan turun. Pada saat tekanan turun, kekuatan manset menekan pembuluh darah juga akan turun sehingga pembuluh nadi kembali melebar dan aliran darah berjalan normal.

Bersamaan dengan itu, stetoskop diletakkan di lengan dekat arteri brachialis untuk mendengar denyut nadi. Saat terdengar denyut nadi untuk pertama kalinya, tekanan pada manset perlahan-lahan akan berubah dan perubahan tekanan akan terdeteksi oleh sensor tekanan MPX5050DP yang kemudian di proses oleh mikrokontroler sebagai tekanan systole dan tombol reset segera di tekan. Data tekanan darah systole yang tampil di LCD langsung dicatat kemudian tombol reset dilepaskan sampai terdengar denyut nadi terakhir melaui stetoskop yang merupakan tekanan darah dyastole. Alat ukur standar yang digunakan sebagai pembanding adalah sphygmomanometer analog.

Pengujian detak jantung dilakukan dengan menjepitkan salah satu ujung jari ke pulse sensor. Pulse sensor memiliki tiga kabel sambungan, kabel yang berwarna merah dihubungkan ke sumber tegangan $+5 \mathrm{~V}$, kabel yang berwarna hitam dihubungkan ke ground, dan kabel yang berwarna ungu dihubungkan ke ouput. Skematik modul alat ukur medical check-up dapat dilihat pada Gambar 1.

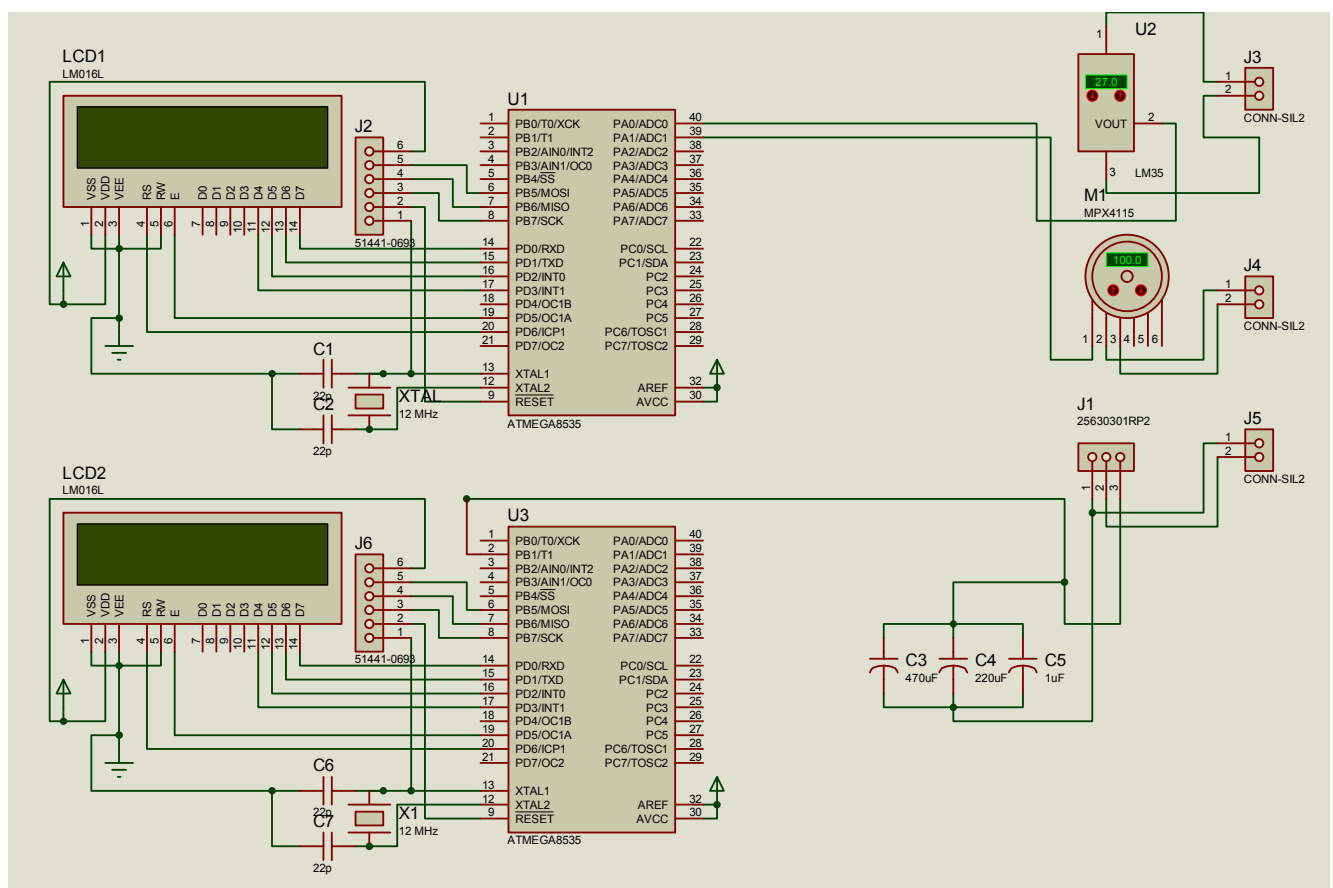

Gambar 1 Skematik modul alat ukur medical check-up

\section{HASIL DAN DISKUSI}

\subsection{Pengujian Catudaya}

Rancang bangun modul alat ukur medical check-up membutuhkan catudaya dengan tegangan $+5 \mathrm{~V},+12 \mathrm{~V}$ dan $-12 \mathrm{~V}$. Catudaya $+5 \mathrm{~V}$ digunakan untuk rangkaian sistem sensor temperatur tubuh, tekanan darah, detak jantung, dan rangkaian sistem minimum mikrokontroler. Selain itu, catudaya $+12 \mathrm{~V}$ dan $-12 \mathrm{~V}$ digunakan untuk rangkaian penguat tak-membalik dan rangkaian schmitt trigger yang ternyata tidak berpengaruh dengan tingkat keberhasilan alat. 
Hasil pengukuran tegangan keluaran tiga catudaya tersebut dapat dilihat pada Tabel 1 . Pada Tabel 1, catudaya $+5 \mathrm{~V}$ menghasilkan tegangan keluaran $5.00 \mathrm{~V}$ dan $5.01 \mathrm{~V}$. Nilai tegangan ini sudah mendekati nilai yang sebenarnya sehingga aman digunakan untuk rangkaian yang bersangkutan.

Tabel 1 Pengujian catudaya $+5 \mathrm{~V},+12 \mathrm{~V}$ dan $-12 \mathrm{~V}$

\begin{tabular}{|c|c|c|c|}
\hline No & $\begin{array}{c}\text { Tegangan } \\
\text { keluaran } \\
\text { catudaya }+5 \mathrm{~V}\end{array}$ & $\begin{array}{c}\text { Tegangan } \\
\text { keluaran } \\
\text { catudaya }+12 \mathrm{~V}\end{array}$ & $\begin{array}{c}\text { Tegangan } \\
\text { keluaran } \\
\text { catudaya }-12 \mathrm{~V}\end{array}$ \\
\hline 1 & 5,00 & 12,02 & $-11,95$ \\
\hline 2 & 5,01 & 12,03 & $-11,95$ \\
\hline 3 & 5,00 & 12,02 & $-11,95$ \\
\hline
\end{tabular}

\subsection{Pengujian Sistem Minimum Mikrokontroler ATmega8535}

Pengujian sistem minimum mikrokontroler ATmega8535 diperlukan untuk mengetahui rangkaian sistem minimum mikrokontroler telah benar dan dapat digunakan untuk keperluan selanjutnya. Proses ini dilakukan dengan cara memasukkan atau menanamkan sebuah program sederhana, yang nantinya akan menampilkan beberapa karakter huruf pada Liquid Crystal Display (LCD).

Program ini dibuat dalam bahasa BASCOM-AVR yang di-compile oleh codevision-AVR dan ditanamkan pada mikrokontroler ATmega8535 melalui sebuah USB downloader (DT-HIQ AVR USB ISP) serta menggunakan personal computer dengan aplikasi AVR Studio 4. Program ini cukup sederhana, awalnya dilakukan inisialisasi mikrokontroler dan besar frekuensi (Hz) kristal yang digunakan. Selanjutnya, penentuan konfigurasi pin LCD terhadap pin mikrokontroler. Terakhir dilakukan intruksi untuk menampilkan beberapa karakter dari kode ASCII (suatu kode yang dimengerti komputer untuk menampilkan huruf abjad) pada lokasi yang diinginkan dalam sebuah LCD.

Setelah proses penanaman program selesai, maka dilanjutkan pengujian dengan cara menginput sumber tegangan $+5 \mathrm{~V}$ pada rangkaian sistem minimum mikrokontroler ATmega8535 dan melihat tampilan pada layar LCD. Hasil pengujian dapat dilihat pada Gambar 2.

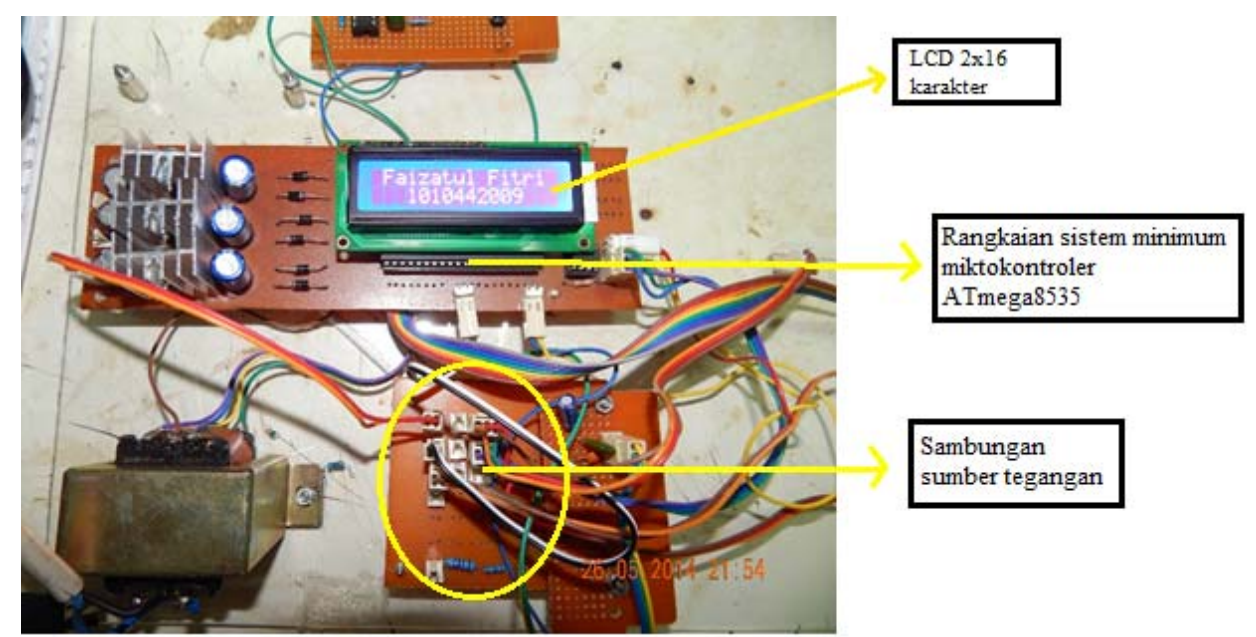

Gambar 2 Pengujian sistem minimum mikrokontroler ATmega8535

Pada Gambar 1, terlihat kode ASCII yang diintruksikan pada program dapat tampil pada layar LCD. Selain pengujian terhadap sistem minimum mikrokontroler ATmega8535, 
pengujian juga dilakukan terhadap penampil LCD sehingga rangkaian sistem minimum mikrokontroler ATmega8535 terangkai dengan baik dan LCD juga dalam kondisi yang baik.

\subsection{Karakterisasi ADC Mikrokontroler ATmega8535}

Karakterisasi ADC Mikrokontroler ATmega8535 dilakukan dengan cara memberikan tegangan input yang bervariasi pada Port A.0 yang merupakan salah satu pin ADC, hal ini bertujuan untuk mengetahui ADC berfungsi dengan baik. ADC dalam kondisi baik ditentukan dengan cara melihat hasil konversi tegangan analog menjadi data digital sudah sesuai dengan perhitungan secara teori. Data karakterisasi ADC dapat dilihat pada Tabel 2.

Tabel 2 Karakterisasi ADC Mikrokontroler ATmega8535

\begin{tabular}{|c|c|c|}
\hline No & $\begin{array}{c}\text { Tegangan input } \\
\text { (volt) }\end{array}$ & Desimal ADC \\
\hline 1 & 0,52 & 106 \\
\hline 2 & 0,95 & 194 \\
\hline 3 & 1,75 & 360 \\
\hline 4 & 2,06 & 424 \\
\hline 5 & 2,76 & 561 \\
\hline 6 & 3,03 & 624 \\
\hline 7 & 3,37 & 689 \\
\hline 8 & 3,84 & 789 \\
\hline 9 & 4,20 & 866 \\
\hline 10 & 4,58 & 937 \\
\hline
\end{tabular}

Sistem minimum mikrokontroler ATmega8535 memiliki ADC internal dengan resolusi 10 bit yang berarti nilai desimalnya adalah $2^{10}-1$. Untu $\mathrm{k}$ tegangan referensi $+5 \mathrm{~V}$ resolusi ADC dapat dihitung seperti berikut:

$$
\text { Resolusi } \mathrm{ADC}=\frac{5 \mathrm{~V}}{2^{n}-1}=\frac{5 \mathrm{~V}}{1023}=4,89
$$

Jadi untuk 1 nilai desimal dari ADC mewakili 4,89 mV. Tegangan masukan 0,52 V akan menghasilkan nilai desimal 106 seperti yang dapat dilihat pada Tabel 2, perhitungannya adalah sebagai berikut:

$$
\text { Desimal ADC }=\frac{V_{\text {in }}}{\text { Resolusi ADC }}=\frac{0,52}{4,89}=106
$$

Hasil perhitungan tersebut sama dengan hasil karakterisasi yang berarti ADC ini berfungsi dengan baik dan nilai desimalnya linier terhadap tegangan masukan seperti yang ditunjukkan pada Gambar 3. 


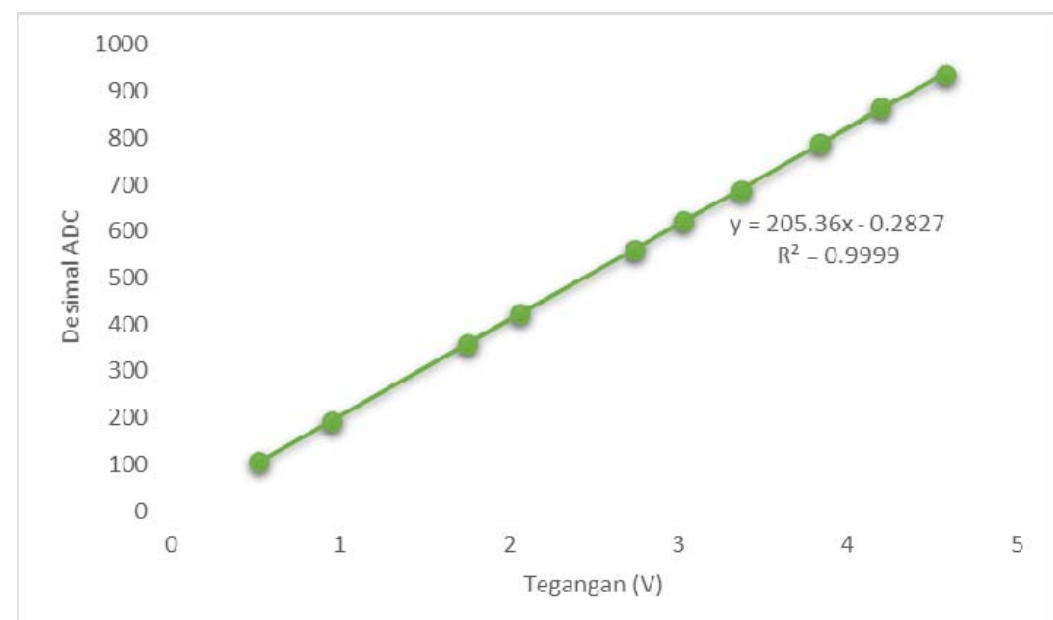

Gambar 3 Grafik tegangan terhadap desimal ADC mikrokontroler ATmega8535

\subsection{Karakterisasi Sensor Temperatur LM35}

Karakterisasi sensor temperatur LM35 dilakukan dengan membandingkan variasi temperatur tubuh manusia dengan tegangan keluaran sensor dari multimeter digital. Data karakterisasi sensor temperatur LM35 dapat dilihat pada Tabel 3. Berdasarkan Tabel 3 dapat diketahui bahwa nilai rata-rata temperatur adalah $34,4{ }^{\circ} \mathrm{C}$, sedangkan nilai rata-rata tegangan keluarannya adalah $0,338 \mathrm{~V}$. Prinsip kerja sensor temperatur LM35 ketika temperatur bernilai 34,4 maka tegangan keluarannya adalah 0,344 sehingga sensor temperatur LM35 ini memilki nilai error sebsesar 0,006. Nilai error dapat terjadi karena sensor temperatur LM35 dapat menghasilkan panas (self-heating) dari sensor yaitu kurang dari $0,5{ }^{\circ} \mathrm{C}$ pada temperatur $25^{\circ} \mathrm{C}$ sehingga menyebabkan kesalahan pembacaan yang rendah serta error dapat juga disebabkan pengaruh temperatur ruangan yang terukur oleh sensor temperatur LM35. Namun, karena nilai errornya sangat kecil, maka sensor temperatur LM35 masih sangat layak untuk digunakan.

Tabel 3 Karakterisasi sensor temperatur LM35

\begin{tabular}{|c|c|c|}
\hline No & $\begin{array}{c}\text { Temperatur } \\
\left({ }^{0} \mathrm{C}\right)\end{array}$ & $\begin{array}{c}\text { Tegangan } \\
\text { (volt) }\end{array}$ \\
\hline 1 & 32,4 & 0,32 \\
\hline 2 & 33,5 & 0,33 \\
\hline 3 & 33,9 & 0,33 \\
\hline 4 & 34,2 & 0,34 \\
\hline 5 & 34,7 & 0,34 \\
\hline 6 & 35,5 & 0,35 \\
\hline 7 & 36,6 & 0,35 \\
\hline $\begin{array}{c}\text { Jumlah } \\
\text { rata-rata }\end{array}$ & 34,4 & 0,33 \\
\hline
\end{tabular}

Karakterisasi dilakukan sebanyak 7 kali dengan nilai temperatur paling tinggi adalah 36,6 ${ }^{\circ} \mathrm{C}$. Grafik karakterisasi sensor temperatur LM35 dapat dilihat pada Gambar 4. 


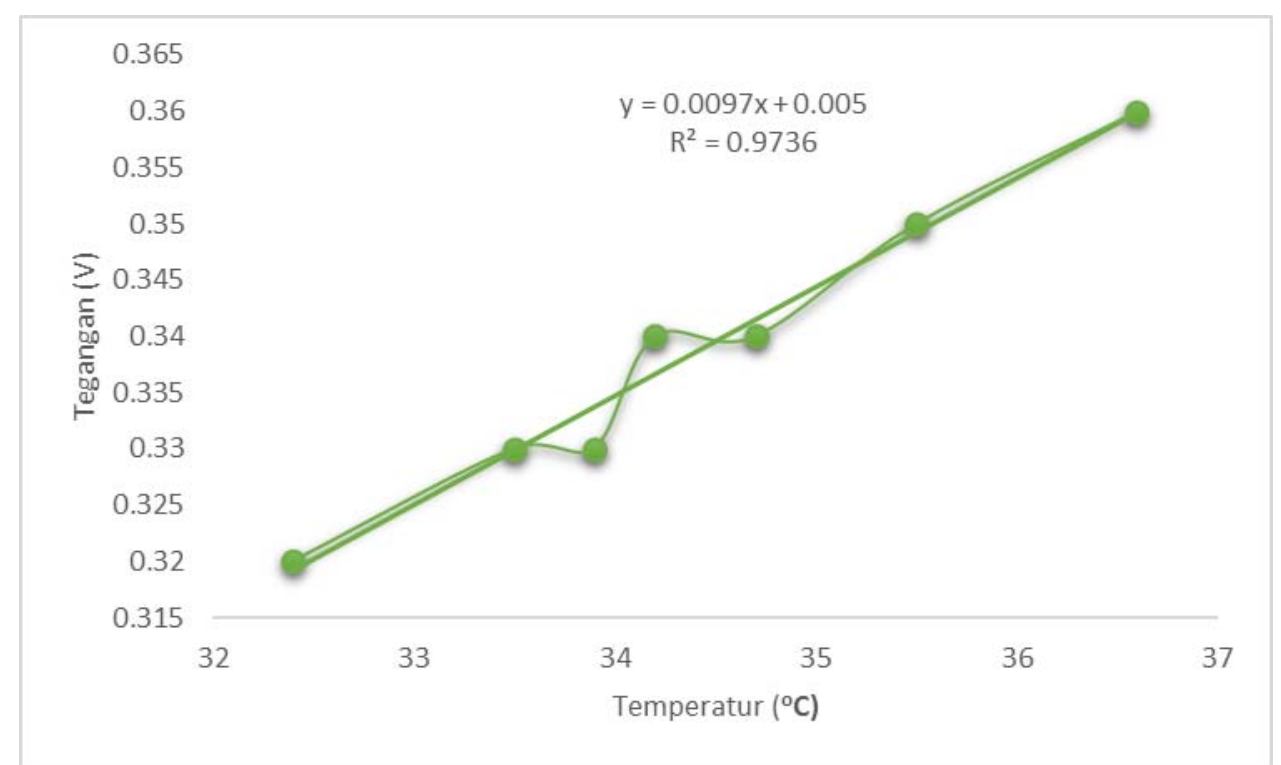

Gambar 4 Grafik temperatur tubuh terhadap tegangan keluaran sensor temperatur LM35

Dari Gambar 4 dapat dilihat bahwa pada pengukuran ketiga dan keempat terdapat perbedaan yang cukup jauh, hal ini dikarenakan faktor temperatur tubuh relawan yang diukur juga berbeda cukup jauh. Gambar 4 memperlihatkan koefisien korelasi karakterisasi sensor temperatur LM35 adalah 0,9736 sehingga dapat disimpulkan bahwa sensor temperatur LM35 memiliki linieritas yang tinggi, keakuratan yang tinggi dan sudah sesuai dengan karakteristik yang telah ditetapkan sehingga dapat digunakan untuk mengukur temperatur tubuh.

\subsection{Karakterisasi Sensor Tekanan MPX5050DP}

Karakterisasi sensor tekanan MPX5050DP dilakukan dengan membandingkan variasi tekanan yang mengalir ke sensor dengan tegangan keluaran sensor dari multimeter digital. Data karakterisasi sensor tekanan MPX5050DP dapat dilihat pada Tabel 4.

Tabel 4 Karakterisasi sensor tekanan MPX5050DP

\begin{tabular}{|c|c|c|}
\hline No & Tekanan $(\mathrm{mmHg})$ & Tegangan (volt) \\
\hline 1 & 6,56 & 0,28 \\
\hline 2 & 10,32 & 0,32 \\
\hline 3 & 18,38 & 0,42 \\
\hline 4 & 41,208 & 0,72 \\
\hline 5 & 45,27 & 0,75 \\
\hline 6 & 55,66 & 0,89 \\
\hline 7 & 64.02 & 0,96 \\
\hline 8 & 83,98 & 1,24 \\
\hline 9 & 136,96 & 1,84 \\
\hline 10 & 154,07 & 2,14 \\
\hline
\end{tabular}

Pada Tabel 4, terlihat bahwa hubungan antara tekanan dan tegangan berbanding lurus. Sensor tekanan MPX5050DP merupakan sebuah integrated circuit (IC) yang terbuat dari tranduser piezoresistif yang terdiri dari diafragma silikon monokristal dengan empat piezoresistif strain gauge yang terbentuk secara penggabungan dalam konfigurasi 
jembatan Wheatstone untuk mengukur tegangan (stress) yang timbul karena tekanan yang diberikan.

Pada sensor tekanan piezoresistif elemen elastisnya adalah diafragma silikon datar. Diafragma merupakan bidang plat lingkaran tipis yang secara luas digunakan sebagai elemen sensing karena memiliki akurasi tinggi dan respon dinamik yang baik. Ketika udara dialirkan ke sensor MPX5050DP, diafragma mengalami penyimpangan karena adanya tekanan sehingga muncul regangan (strain) pada strain gauge yang menyebabkan terjadinya perubahan resistansi pada piezoresistif. Perubahan resistansi sebanding dengan perubahan tegangan sehingga semakin besar tekanan yang diberikan maka semakin besar pula tegangan keluarannya.

Sensitivitas sensor tekanan MPX5050DP sebesar $90 \mathrm{mV} / \mathrm{Kpa}$. Dimana harga tekanan per $1 \mathrm{Kpa}=7.50061683 \mathrm{mmHg}$. Jika tekanan darah manusia yang akan diukur dibatasi pada nilai $200 \mathrm{mmHg}$, maka sensor ini akan mendeteksi tekanan hingga $26.6 \mathrm{Kpa}$ sehingga tegangan keluaran sensor tekanan MPX5050DP menjadi $2394 \mathrm{mV}(2.394 \mathrm{~V})$.

Tegangan referensi mikrokontroler ATmega8535 adalah $5 \mathrm{~V}$. Jika dilihat dari nilai tegangan keluaran sensor tekanan MPX5050DP sebenarnya sensor tekanan MPX5050DP masih memerlukan penguatan agar tegangan keluarannya sesuai dengan tegangan referensi sehingga data analog yang masuk ke mikrokontroler dapat diolah kedalam bentuk data digital. Namun, karena sensor ini dilengkapi dengan chip signal conditioned maka keluaran sensor tidak perlu dikuatkan lagi. Grafik dari Tabel 4 dapat dilihat pada Gambar 5.

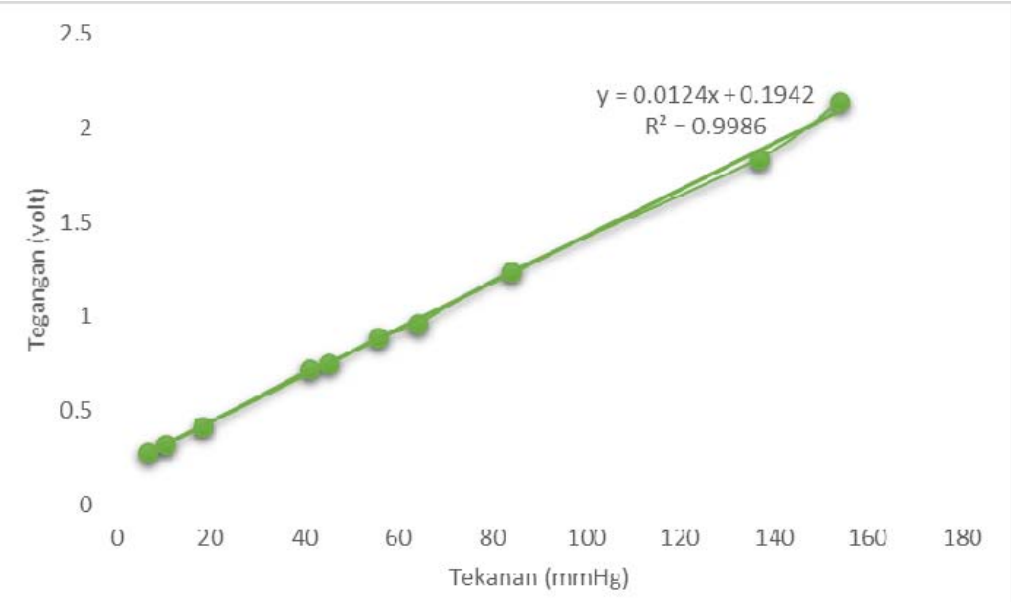

Gambar 5 Grafik tekanan terhadap tegangan keluaran sensor tekanan MPX5050DP

\subsection{Pengujian Modul Alat Ukur Medical Check-Up}

Dalam pengujian ini, ketiga sistem sensor akan dipasang secara bersamaan dengan pengujian temperatur tubuh di jari tangan sebelah kiri, tekanan darah di lengan tempat terdapatnya arteri brachialis, dan detak jantung di jari tangan sebelah kanan. Pengujian modul alat ukur medical chekc-up ini menggunakan 2 rangkaian sistem minimum mikrokontroler ATmega8535 dan 2 buah LCD 2x16 karakter karena ternyata pengukuran detak jantung tidak bisa digabungkan dengan pengukuran temperatur tubuh dan tekanan darah. Hal ini disebabkan karena pengukuran detak jantung memakai sistem counter yaitu perhitungan dilakukan setiap 1 menit sedangkan pengukuran temperatur tubuh dan tekanan darah adalah pengukuran yang melibatkan ADC mikrokontroler yang nilainya akan selalu berubah setiap terjadi perubahan input. 
Sebelumnya penulis sudah mencoba menggabungkan hasil pengukuran modul alat ukur medical check-up dalam satu buah LCD 2x16 karakter dan hasilnya nilai temperatur tubuh dan tekanan darah tidak berubah, dan perubahan terjadi setelah 1 menit begitupun seterusnya. Kemudian dicoba dengan mengganti listing program dengan instruksi yang berbeda dan hasilnya tetap tidak berhasil. Sehingga didapatkanlah kesimpulan bahwa konfigurasi counter tidak bisa digabungkan dengan konfigurasi ADC dalam pemrogramannya. Proses dan hasil pengujian modul alat ukur medical check-up dapat dilihat pada Gambar 6.

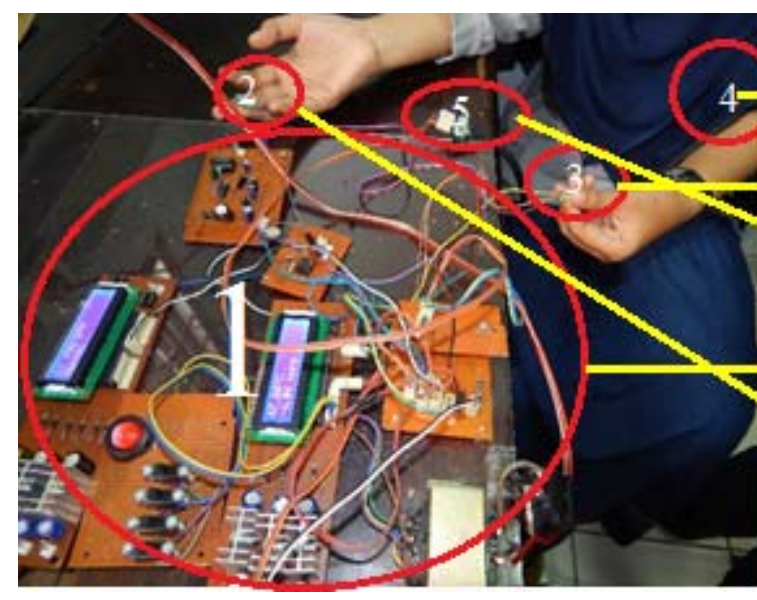

\section{Manset}

Sensor LM35

Sensor MPX5050DP

Rangkaian modul alat ukur medical check-up

Pulse sensor

Gambar 6 Pengujian modul alat ukur medical check-up

Data dan pengolahan data hasil pengujian modul alat ukur medical check-up dapat dilihat pada Tabel 5 dan persentase ketepatan modul alat ukur medical check-up untuk masingmasing sistem sensor dapat dilihat pada Tabel 6 .

Tabel 5 Hasil pengujian modul alat ukur medical check-up

\begin{tabular}{|c|c|c|c|c|c|c|c|}
\hline \multirow[b]{2}{*}{ No } & \multirow[b]{2}{*}{$\begin{array}{c}\text { Subjek } \\
\text { pengukuran }\end{array}$} & \multicolumn{2}{|c|}{ Temperatur tubuh $\left({ }^{\circ} \mathrm{C}\right)$} & \multicolumn{2}{|c|}{ Tekanan darah $(\mathrm{mmHg})$} & \multicolumn{2}{|c|}{ Detak jantung (BPM) } \\
\hline & & $\begin{array}{c}\text { Termometer } \\
\text { digital }\end{array}$ & $\begin{array}{c}\text { Modul alat } \\
\text { ukur medical } \\
\text { check-up }\end{array}$ & $\begin{array}{l}\text { Spygmomanometer } \\
\text { analog }\end{array}$ & $\begin{array}{c}\text { Modul alat } \\
\text { ukur medical } \\
\text { check-up }\end{array}$ & Stetoskop & $\begin{array}{l}\text { Modul alat } \\
\text { ukur medical } \\
\text { check-up }\end{array}$ \\
\hline 1 & Relawan 1 & 35,4 & 35,8 & $120 / 80$ & $117 / 70$ & 85 & 85 \\
\hline 2 & Relawan 2 & 34,2 & 34,7 & $80 / 50$ & $80 / 60$ & 63 & 65 \\
\hline 3 & Relawan 3 & 34,7 & 34,9 & $130 / 80$ & $127 / 70$ & 90 & 88 \\
\hline 4 & Relawan 4 & 35,7 & 35,6 & $110 / 80$ & $106 / 75$ & 70 & 79 \\
\hline 5 & Relawan 5 & 34,0 & 34,5 & $110 / 60$ & $110 / 60$ & 70 & 72 \\
\hline 6 & Relawan 6 & 36,0 & 36,0 & $120 / 70$ & $110 / 60$ & 68 & 75 \\
\hline 7 & Relawan 7 & 35,9 & 36,0 & $110 / 70$ & $105 / 60$ & 72 & 78 \\
\hline 8 & Relawan 8 & 34,2 & 35,0 & $110 / 70$ & $108 / 62$ & 75 & 78 \\
\hline 9 & Relawan 9 & 34,8 & 35,0 & $100 / 50$ & $99 / 55$ & 78 & 96 \\
\hline 10 & Relawan 10 & 34,4 & 34,8 & $110 / 60$ & $108 / 65$ & 78 & 101 \\
\hline
\end{tabular}


ISSN 1979-4657

Tabel 6 Persentase ketepatan modul alat ukur medical check-up masing-masing sistem sensor

\begin{tabular}{|c|c|c|c|c|}
\hline \multirow{2}{*}{ No } & \multicolumn{4}{|c|}{ Persentase ketepatan (\%) } \\
\cline { 2 - 4 } & \multirow{2}{*}{$\begin{array}{c}\text { Temperatur } \\
\text { tubuh }\end{array}$} & \multicolumn{2}{|c|}{ Tekanan darah } & \multirow{2}{*}{ Detak jantung } \\
\cline { 3 - 4 } & 98,87 & 97,50 & 87,50 & 100 \\
\hline 1 & 83,04 & 100 & 80,00 & 96,82 \\
\hline 2 & 99,19 & 97,69 & 87,50 & 97,77 \\
\hline 3 & 99,88 & 96,36 & 93,75 & 87,14 \\
\hline 4 & 98,52 & 100 & 100 & 97,14 \\
\hline 5 & 99,86 & 91,66 & 85,71 & 89,70 \\
\hline 6 & 99,72 & 95,45 & 85,71 & 91,66 \\
\hline 7 & 97,63 & 98,18 & 88,57 & 96,00 \\
\hline 8 & 99,36 & 99,00 & 90,00 & 76,92 \\
\hline 9 & 98,77 & 98,18 & 91,00 & 70,51 \\
\hline 10 & & & & Dyastole \\
\hline
\end{tabular}

Tabel 6 menjelaskan persentase ketepatan modul medical check-up lebih rendah daripada persentase ketepatan pengujian masing-masing sistem sensor. Hal ini dapat terjadi karena kompleksitas rangkaian makin meningkat. Sehingga setiap noise atau gangguan yang muncul pada masing-masing sistem sensor akan bertambah karena akan saling mempengaruhi.

Dalam pengujian modul medical check-up yang pertama diukur adalah detak jantung karena detak jantung akan terus meningkat seiring dengan peningkatan denyut nadi sehingga jika dalam pengujian modul medical check-up, pengujian detak jantung dilakukan secara bersamaan dengan pengujian tekanan darah maka hasil pengujian detak jantung tidak akan akurat.

Modul alat ukur medical check-up hanya dilakukan pada usia dewasa muda yaitu mulai dari usia 18 tahun - 40 tahun. Untuk sistem sensor tekanan darah masih menggunakan pemompa manual untuk mengalirkan udara ke dalam sensor MPX5050DP. Hasil pengujian modul alat ukur medical check-up ditampilkan dalam 2 LCD dikarenakan pada penelitian ini konfigurasi counter tidak bisa digabungkan dengan konfigurasi ADC dalam pemrogramannya dan penulis belum menemukan motode dan pemrograman lain untuk menggabungkannya.

Dalam pengujian modul alat ukur medical check-up persentase ketepatan tertinggi terjadi pada pengujian temperatur tubuh dengan nilai ketapatan sebesar $97.48 \%$ dan persentase ketepatan yang paling rendah terjadi pada pengujian tekanan darah dyastole dengan nilai ketepatan sebesar $89.04 \%$.

\section{KESIMPULAN}

Berdasarkan penelitian dan analisis yang telah dilakukan, maka dapat disimpulkan bahwa modul alat ukur medical check-up untuk temperatur tubuh, tekanan darah, dan detak jantung telah berhasil dirancang dengan ketepatan pengujian temperatur tubuh sebesar $97.48 \%$, tekanan darah systole sebesar $97.40 \%$, tekanan darah dyastole sebesar $89.04 \%$, detak jantung sebesar $90.36 \%$. Modul alat ukur medical check-up menggunakan 2 buah LCD 2x16 karakter sebagai penampil hasil pengukuran. Temperatur tubuh dan tekanan 
darah ditampilkan dalam 1 LCD, sedangkan detak jantung ditampilkan pada LCD lainnya. Ketiga besaran yang diukur tidak bisa ditampilkan dalam 1 LCD karena pengukuran detak jantung menggunakan sistem counter sedangkan pengukuran temperatur tubuh dan tekanan darah melibatkan ADC mikrokontroler yang nilainya berubah setiap terjadi perubahan input.

\section{DAFTAR PUSTAKA}

1. Anita R., dkk., 2012, Rancang Bangun Alat Pengukur Suhu Tubuh Dengan Tampilan Digital dan Keluaran Suara Berbasis Mikrokontroller AVR ATmega8535, Jurnal Program Studi Sistem Komputer, Fakultas Narotama Surabaya, Surabaya.

2. Marnis, Y. 2009. Rancang Bangun Tensimeter Berbasis Mikrokontroler AT89S1 dengan Sensor Tekanan MPX2100DP. Skripsi. Universitas Andalas, Padang.

3. Shaleh, A., dan Budikarso A., 2009, Rancang Bangun Pendeteksi Suhu Tubuh, Tekanan Darah dan Detak Jantung untuk Medical check Up, Jurnal Politeknik Elektronika Negeri Surabaya, Institut Teknologi Sepuluh November (ITS), Surabaya.

4. Yazid N. dan Harjoko A., 2011, Pemantau Tekanan Darah digital Berbasis Sensor Tekanan MPX2050GP, Jurnal Universitas Gadjah Mada, Yogyakarta. 